\title{
PLATELET ALPHA 2 ADRENORECEPTORS ARE DECREASED IN NUMBER AFTER ANTIDEPRESSANT THERAPY
}

\author{
CHARLES B. SMITH, PEGGIE J. HOLLINGSWORTH, JESUS A. \\ GARCIA-SEVILLA AND ATHANASIOS P. ZIS \\ Departments of Pharmacology and Psychiatry \\ University of Michigan Medical School, Ann Arbor, MI, USA
}

(Final form, December 1982)

\section{Contents}

$\begin{array}{llr} & \text { Abstract } & 241 \\ \text { 1. Introduction } & 242 \\ \text { 2. Alpha adrenoreceptors in experimental animals } & 242 \\ \text { 3. Alpha adrenoreceptors on human blood platelets } & 242 \\ \text { 4. Receptor binding studies in endogenously depressed patients } & 242 \\ 4.1 \text { Subjects studied } & 242 \\ 4.2 \text { Platelet reçeptor binding teçhiques } & 243 \\ 4.3 \text { Binding of H-clonidine and H-yohimbine to platelet } & 243 \\ \text { 5. } \text { Other psychiatric and non-psychiatric disorders } & 244 \\ \text { 6. Effects of antidepressant therapy } & 244 \\ \text { 7. Conclusions } & 245 \\ & \text { References }\end{array}$

\section{Abstract}

Smith, Charles B., Peggie J. Hollingsworth, Jesus A. Garcia-Sevilla and Athanasios P. Zis: Platelet alpha adrenoreceptors are decreased in number after antidepressant therapy. Prog. Neuro-Psychophârmacol. \& Biol. Psychiat. 1983, 7(2/3): 241-247.

1. Specific binding of ${ }^{3} \mathrm{H}$-clonidine to alpha adrenoreceptors upon human blood platelet membranes is increased in patients with major depressive disorder (endogenous depression).

2. Specific binding of ${ }^{3} \mathrm{H}$-yohimbine to the platelet adrenoreceptor is not altered in endogenously depressed patients.

3. Other psychiatric disorders are ${ }_{3}$ not associated with alterations in the specific

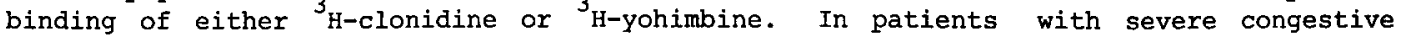
heart failure or with symptomatic coronary artery disease the number of platelet alpha 2 adrenoreceptors is actually decreased.

4. Treatment of endogenously depressed patients with tricyclic antidepressants, lithium salts or electroconvulsive therapy results in a decrease in the number of alpha adrenoreceptors on blood platelet membranes.

5. These studies suggest that a supersensitivity of the alpha adrenoreceptor might exist in patients with endogenous depression and that effective forms of therapy lead to a decrease in the number of neural alpha adrenoreceptors which is reflected by $a$ decrease in the number of these receptors upon ${ }^{2}$ blood platelet membranes.

Key words: alpha, adrenoreceptors, electroconvulsive therapy, human blood platelets, lithium salts, major depressive disorder, tricyclic antidepressants 


\section{Introduction}

The amine theory of depression postulates that the biological basis of endogenous depression (Major Depressive Disorder) is a lack of adequate neuronal release of amine neurotransmitters such as norepinephrine and serotonin (Bunney and Davis, 1965; Schildkraut, 1965). In recent years presynaptic receptors have been shown to play an important role in the regulation of neurotransmitter release (Langer, 1977, 1980; Starke, 1977, 1981; Westfall, 1977). Feedback inhibition of norepinephrine release by norepinephrine located in the synaptic cleft seems to be the primary means by which the release of this neurotransmitter is regulated. Stimulation of the presynaptic alpha adrenoreceptor mediates this inhibition of neurotransmitter release. It has been postulated that a supersensitivity of this receptor exists in the endogenous type of depression and that one result of treatment of this disease is a decrease in the sensitivity of this receptor (Garcia-Sevilla et al., 1981b; Smith et al., 1981; Smith and Garcia-Sevilla, 1982).

\section{Alpha 2 Adrenoreceptors in Experimental Animals}

Several studies have shown that forms of therapy which are efficacious in the treatment of endogenous depression result in either a functional subsensitivity of the alpha adrenoreceptor (Crews and Smith, 1978) or a decrease in the number of these receptors located upon neural membranes isolated from the brains of experimental animals. Early functional studies in our laboratory showed that the long-term administration of tricyclic antidepressant drugs caused decreased sensitivity of alpha ${ }_{2}$ adrenoreceptors located upon noradrenergic neurons in the rat heart. Drugs which after chronic administration led to increased neuronal release of norepinephrine in the rat heart included both typical (clomipramine, desipramine and nortriptyline) and atypical (ipxindole) tricyclic antidepressants (Crews and Smith, 1980 ). Later, long-term administration of amitriptyline to rats was found to decrease the number of alpha, adrenoreceptors present in certain areas of the rat brain (Smith et al., 1981). Long-Eerm administration of clorgyline, a monoamine oxidase inhibitor, also has been shown to decrease the number of alpha, adrenoreceptors located upon neural membranes isolated from rat cerebral cortex (Cohen et al., 1982). Recently, the repeated administration of electroconvulsive shock to rats was found to decrease the number of alpha adrenoreceptors located upon neural membranes isolated from cerebral cortex, hippocampus and hypothalamus (Stanford and Nutt, 1982). Thus, a variety of different types of treatment for depressive illness all result in decreases in the number of alpha ${ }_{2}$ adrenoreceptors upon neurons in the rat brain.

\section{Alpha 2 Adrenoreceptors on Human Blood Platelets}

Our studies with experimental animals led us to explore the possibility that endogenous depression might be associated with alpha adrenoreceptor supersensitivity and that treatment would result in decreases in the number of these receptors located in the contral nervous system. The alpha adrenoreceptor has been found in a variety of nonneural tissues such as rat renal cortex (Woodcock et al., 1980), hamster adipocytes (Garcia-Sainz et al., 1980), human fat cells (Berlan and IaFontan, 1980, Tharp et a1., 1981) and human blood platelets (Motulsky et al., 1980; Garcia-Sevilla et al., 1981a; Shattil et al., 1981). The human blood platelet has been used often as a model to evaluate changes in nerve cell function in patients with psychiatric disorders (Stahl, 1977). The blood platelet possesses alpha adrenoreceptors which when stimulated are responsible for the initiation of platelet aggregation by catecholamines (Ardlie et al., 1966). Numerous recent studies have produced clear evidence that this adrenoreceptor is of the alpha subtype. The present paper reviews studies done in our laboratory upon platelet alpha adrenoreceptors in a variety of patients with psychiatric and nonpsychiatric disorders. Changes in the platelet alpha adrenoreceptor after treatment of endogenously depresssed patients with various forms of therapy will be discussed.

\section{Receptor Binding Studies in Endogenously Depressed Patients}

\subsection{Subjects Studied}

Receptor binding techniques provide a powerful means of evaluating changes in the number 


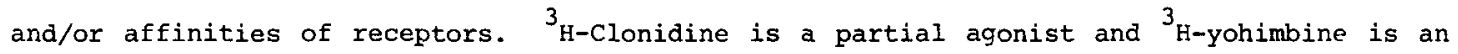
antagonist which have high affinity for the alpha, adrenoreceptor (Greenberg, et al., 1976; Y'Prichard et al., 1977). During the past three years the binding of either H-clonidine or 3 H-yohimbine, or both ligands, to isolated platelet membranes has been determined in a sizeable population of patients with a variety of clinical conditions. Among these were patients with the following diagnoses: major depressive disorder, other depressive disorders, panic disorder, severe congestive heart failure and symptomatic coronary artery disease. Psychiatric patients were evaluated and treated in the Department of Psychiatry and patients with cardiovascular disorders in the Cardiology Unit, University of Michigan Medical Center, Ann Arbor. The procedures for diagnosing major depressive disorder have been described previously (Garcia-Sevilla et al., 1981b). Of a total of 35 drug-free psychiatric patients, the diagnosis of probable or definite major depressive disorder at the time of the initial study was subsequently confirmed by concensus diagnosis in 29 patients. Most of these patients met the criteria for probable or definite endogenous subtype according to Research Diagnostic Criteria. All patients with the exception of those in congestive heart failure were totally drug free for a period of two weeks prior to the initial platelet receptor binding studies. Patients in congestive heart failure were treated at the time of the initial studies with a combination of diuretics and cardiac glycosides, but did not receive ejither adrenergic agonists or antagonists. Specific binding of either 3 H-clonidine or H-yohimbine, or both, to platelet membranes was determined prior to the onset of treatment in a blind manner with respect to the patient's diagnosis. Whenever possible, for the psychiatric patients the determinations were repeated subsequent to treatment with tricyclic antidepressants, lithium carbonate, or after electroconvulsive therapy.

\subsection{Platelet Receptor Binding Techniques}

All determinations were performed upon fresh platelet samples. Preliminary studies were carried out in which the isolated platelet membranes were frozen and stored at $-70^{\circ} \mathrm{C}$ for a period of 7 days. Freezing cauşed significant changes in the number of specific binding sites for both $\mathrm{H}$-clonidine and $\mathrm{H}$-yohimbine. Consequently, only freshly prepared platelet membranes are used in our studies. Approximately $50 \mathrm{ml}$ of blood is collected by venipuncture in plastic centrifuge tubes which contain (8:1 v/v) acid-citrate-dextrose (ACD) solution as anticoagulant (National Institutes of Health Formula A: $0.8 \%$ citric acid, 2.28 trisodium citrate and 2.458 dextrose). The blood is centrifuged at $160 \mathrm{x} \mathrm{g}$ for $10 \mathrm{~min}$ $\left(25^{\circ} \mathrm{C}\right)$ and the resulting platelet-rich plasma is titrated to $\mathrm{pH} 6.5$ with $\mathrm{ACD}$ solution and recentrifuged at $5100 \mathrm{x} \mathrm{g}$ for $15 \mathrm{~min}\left(25^{\circ} \mathrm{C}\right)$ to sediment the platelets. The platelet pellet is washed twice with $5 \mathrm{ml}$ of Tyrode buffer ( $\mathrm{NaCl} 137 \mathrm{mM}$; KCl, $2.7 \mathrm{mM}$; $\mathrm{NaH}_{2} \mathrm{PO} 0.36 \mathrm{mM}$; $\mathrm{MgCl}$, $0.10 \mathrm{mM}$; $\mathrm{NaHCO} 12.0 \mathrm{mM}$; dextrose $0.56 \mathrm{~mm} ; \mathrm{pH} 8.0)$ and recentrifuged at $52^{2} 00^{4} \mathrm{x} \mathrm{g}$ for $15 \mathrm{~min}$. The washed perlet is lysed by homogenization in $2 \mathrm{ml}$ of ice-cold hypotonic buffer (TrisEDTA, $5 \mathrm{mM} ; \mathrm{pH} 7.5)$. After centrifugation at $39000 \mathrm{x} g$ for $10 \mathrm{~min}\left(4^{\circ} \mathrm{C}\right)$, the platelet membranes are resuspended in the Tris inçubation buffer (Tris-HCl, $50 \mathrm{mM}$; $\mathrm{MgCl} 10 \mathrm{mM}$; $\mathrm{pH}$ 7.5) used in the binding assay. Total H-clonidine and H-yohimbine binding is measured with one $\mathrm{ml}$ aliquots of the fresh platelet membranes which are incubated in duplicate with shaking at $25^{\circ} \mathrm{C}$. Nonspecific binding is determined by adding unlabelled clonidine or yohimbine, $10^{-5} \mathrm{M}$, in addition to the labelled ligand, to a second pair of incubates. Specific binding is defined as the difference between total and nonspecific binding. Further details of the experimental procedures have been previously described (Garcia-sevilla et al., $1981 a, b)$.

\subsection{Binding of ${ }^{3} \mathrm{H}-\mathrm{Clonidine}$ and ${ }^{3} \mathrm{H}$-Yohimbine to Platelet Membranes from Endogenously Depressed Patients}

The specific binding of ${ }^{3} \mathrm{H}$-clonidine to platelet alpha adrenoreceptors in a selected group of drug-free patients with major depressive disorder is significantly higher than that obtained in a similar control population (Table 1). Although the specific binding of ${ }^{3}$ H-yohimbine was also increased in the population of patients with major depressive disorder, this increase was smaller than that seen with H-clonidine and was not significant statistically (Table 2). It is possible that the two ligands bind to different forms of the same receptor and that the form of this receptor to which $\mathrm{H}$-clonidine binds is that which is abnormal in patients with major depressive disorder. 
Table 1

Specific Binding of ${ }^{3} \mathrm{H}-\mathrm{Cl}$ onidine to Platelet Alpha Adrenoreceptors in Normal Subjects and Patients with Psychiatric and Non-Psychiatric Disorders

\begin{tabular}{|c|c|c|c|}
\hline Diagnosis & $\begin{array}{c}\mathrm{B}_{\max } \\
\text { (fmoles/mg } \\
\text { protein) }\end{array}$ & $\underset{(n M)}{K_{D}}$ & $\mathrm{n}$ \\
\hline Normal subjects & $\begin{array}{l}32 \\
\pm 2\end{array}$ & $\begin{array}{r}5.5 \\
\pm 0.6\end{array}$ & 26 \\
\hline $\begin{array}{l}\text { Major depressive } \\
\text { disorder }\end{array}$ & $\begin{array}{l}46^{\star \star} \\
\pm 2\end{array}$ & $\begin{array}{r}5.6 \\
\pm 0.6\end{array}$ & 29 \\
\hline $\begin{array}{l}\text { Non-major depres- } \\
\text { sive disorder }\end{array}$ & $\begin{array}{l}29 \\
\pm 6\end{array}$ & $\begin{array}{r}5.1 \\
\pm 0.9\end{array}$ & 6 \\
\hline Panic disorder $\mathbf{S}$ & $\begin{array}{l}36 \\
\pm 4\end{array}$ & $\begin{array}{r}8.5 \\
\pm 1.4\end{array}$ & 9 \\
\hline $\begin{array}{l}\text { Congesitve heart } \\
\text { failure }\end{array}$ & $\begin{array}{l}24^{* \star} \\
\pm 2\end{array}$ & $\begin{array}{r}3.4 \\
\pm 0.6\end{array}$ & 5 \\
\hline $\begin{array}{l}\text { Coronary artery } \\
\text { disease II }\end{array}$ & $\begin{array}{l}30 \\
\pm 3\end{array}$ & $\begin{array}{r}7.3 \\
\pm 1.3\end{array}$ & 5 \\
\hline
\end{tabular}

Each value represents the mean \pm the standard error of the mean. 'B ${ }_{\text {max' }}$ the maximum number of specific binding sites; $K_{1}$, the dissociation constant. max $_{\$}^{\prime}$ Approximately one-half of the patients with panic disorder met the DSM III criteria for agoraphobia with panic disorder. I All of the patients in this category had symptoms of angina pectoris. $n=$ number of subjects. $* \mathrm{P}<.05, * * \mathrm{P}<.0005$.

\section{Other Psychiatric and Non-Psychiatric Disorders}

In patients with panic disorder or in psychiatriç patients who did not meet the criteria for major depressive disorder, specific binding of $\mathrm{H}$-clonidine to platelet alpha adrenoreceptors was the same as to membranes from normal subjects. Specific binding of tritiated yohimbine was actually decreased significantly in those patients with panic disorder. The decrease in H-yohimbine binding might reflect either transient or sustained increases in plasma catecholamine content. Patients with severe congestive heart failure and those with şymptomatic coronary artery disease, also had marked reductions in the specific binding of H-yohimbine. Specific binding of 3 -clonidine was also reduced in patients with severe congestive heart failure, and in these patients there was a good correlation between plasma catecholamine content and the number of platelet alpha ${ }_{2}$ adrenoreceptors.

\section{Effects of Antidepressant Therapy}

Specific binding of either ${ }^{3} \mathrm{H}$-clonidine or ${ }^{3} \mathrm{H}$-yohimbine to platelet membranes has been measured in patients treated with tricyclic antidepressants, lithium carbonate or electroconvulsive therapy (Table 3). These patients were selected because they received no other type of drug therapy. Treatment with either imipramine hydrochloride or with amitriptyline hydrochloride produced significant decreases in the $B_{\max }$ of high affinity binding sites for 
Table 2

Specific Binding of ${ }^{3} \mathrm{H}$-Yohimbine to Platelet Alpha 2 Adrenoreceptors in Normal Subjects and Patients with Psychiatric and Non-Psychiatric Disorders

\begin{tabular}{|c|c|c|c|}
\hline Diagnosis & $\begin{array}{c}\mathrm{B}_{\max } \\
\text { (fmoles/mg } \\
\text { protein) }\end{array}$ & $\underset{(\mathrm{nM})}{\mathrm{K}_{\mathrm{D}}}$ & $\mathrm{n}$ \\
\hline Normal subjects & $\begin{array}{l}165 \\
\pm 12\end{array}$ & $\begin{array}{r}4.0 \\
\pm 0.5\end{array}$ & 16 \\
\hline $\begin{array}{l}\text { Major depressive } \\
\text { disorder }\end{array}$ & $\begin{array}{r}183 \\
\pm 9\end{array}$ & $\begin{array}{r}5.2 \\
\pm 0.8\end{array}$ & 18 \\
\hline Panic disorder $\$$ & $\begin{array}{l}113^{\star *} \\
\pm 19\end{array}$ & $\begin{array}{r}4.1 \\
\pm 0.5\end{array}$ & 8 \\
\hline $\begin{array}{l}\text { Congestive heart } \\
\text { failure }\end{array}$ & $\begin{array}{l}94^{\star *} \\
\pm 9\end{array}$ & $\begin{array}{r}4.4 \\
\pm 0.4\end{array}$ & 9 \\
\hline $\begin{array}{c}\text { Coronary artery } \\
\text { disease }\end{array}$ & $\begin{array}{l}103^{* \star} \\
\pm 7\end{array}$ & $\begin{array}{r}4.4 \\
\pm 0.9\end{array}$ & 13 \\
\hline
\end{tabular}

Each value represents the mean \pm the standard error of the mean. 'Bax' the maximum number of specific binding sites; $K_{D}$, the dissociation constant. 'max' ${ }_{S}^{\prime}$ Approximately one-half of the patients with panic disorder met the DSM III criteria for agoraphobia with panic disorder. I All of the patients in this category had symptoms of angina pectoris. $n=$ number of subjects. $* \mathrm{P}<.05, * * \mathrm{P}<.0005$.

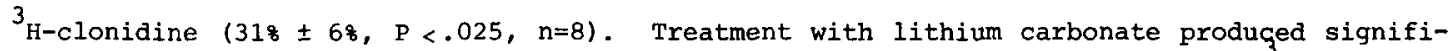
cant decreases in the maximum number of high affinity binding sites for H-yohimbine $\{31 \% \pm 8 \%, P<.05, n=4)$. Electroconvulsive therapy decreased the specific binding of both 3 -clonidine $(498 \pm 48, P<.0005, n=7)$ and $H$-yohimbine $(418 \pm 98, P<.005, n=5)$.

\section{Conclusions}

The number of alpha, adrenoreceptors upon human blood platelet membranes to which ${ }^{3} \mathrm{H}$-clonidine binds specifically is increased in patients who are endogenously depressed. $A$ similar increase in the specific binding of H-yohimbine is not observed. Other psychiatric and nonpsychiatric disorders are not associated with similar alterations in the number of alpha, adrenoreceptors. Treatment of endogenously depressed patients with tricyclic antidepressants, lithium carbonate or electroconvulsive therapy decreases the number of alpha, adrenoreceptors upon platelet membranes. It is suggested that there is a supersensitivity of alpha adrenoreceptors upon neurons in the central nervous system of patients with major depressive disorder and that effective forms of therapy result in a decrease in the number of these receptors which is reflected by a similar change in the number of alpha adrenoreceptors upon blood platelet membranes. 
Table 3

Hligh-affinity Binding of ${ }^{3} \mathrm{H}-\mathrm{Clonidine}$ and ${ }^{3} \mathrm{H}$-Yohimbine to Platelet Membranes Before and After Antidepressant Therapy

\begin{tabular}{|c|c|c|c|c|c|}
\hline & \multicolumn{2}{|c|}{ Drug-free } & \multicolumn{2}{|c|}{ Treated } & \multirow[b]{2}{*}{$\mathrm{n}$} \\
\hline & $\begin{array}{c}\mathrm{K}_{\mathrm{D}} \\
(\mathrm{nM})\end{array}$ & $\begin{array}{c}\mathrm{B}_{\max } \\
\text { (fmoles/mg } \\
\text { protein) }\end{array}$ & $\begin{array}{c}\mathrm{K}_{\mathrm{D}} \\
(\mathrm{nM})\end{array}$ & $\begin{array}{c}\mathrm{B}_{\max } \\
\text { (fmoles } / \mathrm{mg} \\
\text { protein) }\end{array}$ & \\
\hline \multicolumn{6}{|c|}{${ }^{3} \mathrm{H}-\mathrm{Cl}$ onidine Binding } \\
\hline Tricyclics ${ }^{1}$ & $\begin{array}{r}6.5 \\
\pm 1.0\end{array}$ & $\begin{array}{l}48 \\
\pm 5\end{array}$ & $\begin{array}{r}3.9 \\
+0.6\end{array}$ & $\begin{array}{l}33 \\
\pm 3\end{array}$ & 8 \\
\hline $\mathrm{ECT}^{3}$ & $\begin{array}{r}5.3 \\
\pm 1.5\end{array}$ & $\begin{array}{l}53 \\
\pm 6\end{array}$ & $\begin{array}{r}7.8 \\
\pm 1.5\end{array}$ & $\begin{array}{l}27 \\
\pm 2\end{array}$ & 7 \\
\hline \multicolumn{6}{|c|}{${ }^{3} \mathrm{H}-$ Yohimbine Binding } \\
\hline Lithium ${ }^{2}$ & $\begin{array}{r}5.8 \\
\pm \quad 1.0\end{array}$ & $\begin{array}{l}196 \\
\pm \quad 21\end{array}$ & $\begin{array}{r}4.9 \\
+\quad 1.5\end{array}$ & $\begin{array}{l}135 \\
\pm \quad 16\end{array}$ & 4 \\
\hline $\mathrm{ECT}$ & $\begin{array}{r}4.8 \\
+0.8\end{array}$ & $\begin{array}{r}170 \\
\pm 9\end{array}$ & $\begin{array}{r}3.7 \\
\pm 0.3\end{array}$ & $\begin{array}{l}101 \\
\pm 16\end{array}$ & 5 \\
\hline
\end{tabular}

1. Patients were treated either with imipramine hydrochloride (125 to $250 \mathrm{mg} /$ day) or with amitriptyline hydrochloride $(125$ to $150 \mathrm{mg} /$ day $)$ for a period of 2 to 5 weeks.

2. Patients were treated with lithium carbonate (900 to $1500 \mathrm{mg} /$ day) for 3 weeks. 3. Electroconvulsive therapy was administered over a period of 2 to 3 weeks ( 7 to 10 treatments).

\section{Acknowledgements}

These studies were supported in part by a grant from the Michigan Department of Mental Health and USPHS grant MH-36226. We wish to thank Sarah J. Moss and Joann J. Geer for their technical assistance.

\section{References}

ARDLIE, N.B., GLEW, G. and SCHWARTZ, C.J. (1966). Influence of catecholamines on nucleotide-induced platelet aggregation. Nature 212: 415-416.

BERLAN, M. and LAFONTAN, M. (1980). Identification of alpha adrenergic receptors in human fat cell membranes by $\left[{ }^{3} \mathrm{H}\right]$ clonidine binding. Eur. J. Phys. 67: 481-484.

BUNNEY, W.F. and DAVIS, J.M. (1965). Norepinephrine in depressive reactions: A review. Arch. Gen. Psychiat. 13: 483-494.

COHEN, R.M., CAMPBELL, I.C., DAUPHIN, M., TALLMAN, J.F. and MURPHY, D.L. (1982). Changes in $\alpha$ - and $\beta$-receptor densities in rat brain as a result of treatment with monoamine oxidase inhibiting antidepressants. Neuropharmacology 21: 293-298.

CREWS, F.T. and SMITH, C.B. (1978). Presynaptic alpha-receptor subsensitivity after longterm antidepressant treatment. Science 202: 322-324. 
CREWS, F.T. AND SMITH, C.B. (1980). Potentiation of responses to field stimulation of isolated rat left atria during chronic tricyclic antidepressant administration. J. Pharmacol. Exp. Ther. 215: 143-149.

GARCIA-SAINZ, J.A., HOFFMAN, B.B., LI, S-Y, LEFKOWITZ, R.J. and FAIN, J.N. (1980). Role of alpha adrenoreceptors in the turnover of phosphatidylinositol and of alpha adrenoreceptors in the regulation of cyclic AMP accumulation in hamster adipocytes. Life Sci. 27: 953-961.

GARCIA-SEVILLA, J.A., HOLLINGSWORTH, P.J. and SMITH, C.B. (1981a). Alpha adrenoreceptors on human platelets: selective labelling by $\left[{ }^{3} \mathrm{H}\right] c$ lonidine and [ $\left.\mathrm{H}\right]$ yohimbine and competitive inhibition by antidepressant drugs. Eur. J. Pharm. 74: 329-341.

GARCIA-SEVILLA, J.A., ZIS, A.P., HOLLINGSWORTH, P.J., GREDEN, J.F. and SMITH, C.B. (1981b). Platelet $\alpha_{2}$-adrenergic receptors in major depressive disorder. Arch. Gen. Psychiat. 38: 1327-1333.

GREENBERG, D.A., U'PRICHARD, D.C. and SNYDER, S.H. (1976). Alpha-noradrenergic receptor binding in mammalian brain: differential labeling of agonist and antagonist states. Life Sci. 19: $69-76$.

LANGER, S.z. (1977). Presynaptic receptors and their role in the regulation of transmitter release. $\mathrm{Br}$. J. Pharmacol. 60: 481-497.

LANGER, S.z. (1980). Presynaptic regulation of the release of catecholamines. Pharmacol. Rev. $32: 337-362$.

MOTULSKY, H.J., SHATTIL, S.J. and INSEL, P.A. (1980). Characterization of adrenergic receptors on human platelets using [ H]yohimbine. Biochem. Biophys. Res. Commun. 97: 1562-1570.

SCHILDKRAUT, J.J. (1965). The catecholamine hypothesis of affective disorders: A review of supporting evidence. Am. J. Psychiat. 122: 509-522.

SHATTIL, S.J., MCDONOUGH, M., TURNBULL, J. and INSEL, 3 P.A. (1981). Characterization of

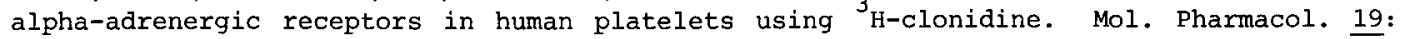
$179-183$.

SMITH, C.B., GARCIA-SEVILLA, J.A. and HOLLINGSWORTH, P.J. (1981). Alpha adrenoreceptors in rat brain are decreased after long-term tricyclic antidepressant ${ }^{2}$ drug treatment. Brain Res. 210: 413-418.

SMITH, C.B. and GARCIA-SEVILLA, J.A. (1982). Alpha 2 adrenoreceptors in endogenous depression. Ad. Biosci. 40:99-106.

STAHL, S.M. (1977). The human platelet: a diagnostic and research tool for the study of biogenic amines in psychiatric and neurologic disorders. Arch. Gen. Psychiat. 34: 509-516.

STANFORD, S.C. and NUTT, D.J. (1982). Comparison of the effects of repeated electroconvulsive shock on $\alpha_{-}$- and $\beta$-adrenoreceptors in different regions of rat brain. Neurosciences 7 : 1753-1757.

STARKE, K. (1977). Regulation of noradrenaline release by presynaptic receptor systems. Rev. Physiol. Biochem. Pharmacol. 77: 1-124.

STARKE, K. (1981). Presynaptic receptors. Ann. Rev. Pharmacol. Toxicol. 21: 7-30.

THARP, M.D., HOFFMAN, B.B., and LEFKOWITZ, R.J. (1981). Alpha-adrenergic receptors in human adipocyte membranes: direct detection by $\left[{ }^{3} \mathrm{H}\right]$ yohimbine binding. J. Clin. Endo. Metab. 52: 709-714.

U'PRICHARD, D.C., GREENBERG, D.A. and SNYDER, S.H. (1977). Binding characteristics of radiolabeled agonist and antagonist at central nervous system alpha noradrenergic receptors. Molec. Pharmacol. 13: 454-473.

WESTFALL, T.C. (1977). Local regulation of adrenergic neurotransmission. Physiol Rev. 57: 659-728.

WOODCOCK, E.A., JOHNSTON, C.I. and OLSSON, C.B. (1980). Alpha adrenergic inhibition of renal cortical adenylate cyclase. J. Cycl. Nucleo. Res. 6: 261-269.

Inquiries and reprint requests should be addressed to:

Dr. Charles B. Smith

Department of Pharmacology

The University of Michigan Medical School

Ann Arbor, MI 48109, USA 